\title{
Investigating the Meanings of Rīh (a wind) and Rīyah (winds) and theirTranslation Issues in the Holy Qur'ān
}

\author{
Abdul-Qader Khaleel Mohammed Abdul-Ghafour \\ School of Language Studies and Linguistics \\ Universiti Kebangsaan Malaysia, Selangor, Malaysia \\ Norsimah Mat Awal \\ School of Language Studies and Linguistics \\ Universiti Kebangsaan Malaysia, Selangor, Malaysia \\ Intan Safinaz Zainudin \\ School of Language Studies and Linguistics \\ Universiti Kebangsaan Malaysia \\ Universiti Kebangsaan Malaysia, Selangor, Malaysia \\ Ashinida Aladdin \\ School of Language Studies and Linguistics \\ Universiti Kebangsaan Malaysia, Selangor, Malaysia
}

\begin{abstract}
This study investigates the meanings of ريح (a wind) and رياح (winds) and their translation issues in the Holy Qur'ân. It aims at identifying the contextual meanings of these words based on different exegeses of the Holy Qur'ān. Then, it explains the nuances that exist between the two lexical items. The study also examines how the shades of meaning of the Qur'ānic words are reflected in two English translations of the Holy Qur'ān, namely, Arberry (2003) and Irving (2002). The study adopts the RC-S approach by Murphy (2003) as a theoretical framework for data analysis. It also employs the qualitative approach to collect and analyze the data of the study. Different exegeses are consulted to identify the differences between the two words. The results reveal that there are some differences in meaning between these Arabic words in Holy Qur'ann and that the shades of meaning of these words are not reflected in the English translations. The study provides recommendations for readers and translators especially the translators of the Holy Qur'ān.
\end{abstract}

Keywords: Affective meaning; connotative meaning; contextual meaning; denotative meaning; Holy Qur'ān meaning and near-synonyms

Cite as: Abdul-Ghafour, A. K. Awal, N. M. Zainudin, I.S. \& (2017). Fansubbing in the Arab World: Modus Operandi and Prospects. Arab World English Journal for Translation \& Literary Studies, 1(1). DOI: http://dx.doi.org/10.24093/awejtls/vol1no1.6 